\title{
Festulolium field performance under fluctuating growing conditions in Lithuania
}

\author{
V. KEMEŠYTĖ, K. JAŠKŪNĖ, and G. STATKEVIČIŪTË* \\ Institute of Agriculture, Lithuanian Research Centre of Agriculture and Forestry, \\ LT-58344 Akademija, Kèdainiai distr., Lithuania
}

\begin{abstract}
Festulolium cultivars are widely utilized in Lithuania because they are persistent under abiotic stresses and are high yielding. However, changing climate challenges the existing Festulolium cultivars to adapt to new growing conditions and still maintain the yield. In this study, we aimed at evaluating the yield stability of two Festulolium cultivars in field trials under fluctuating Lithuanian conditions. The mean total dry matter yield (DMY) of both Festulolium cultivars fluctuated greatly between the years and $A N O V A$ analysis showed a significant effect of environment on total DMY as well as DMY of each cut, but the genotype $\times$ environment interaction was not significant. There was a high difference between the total DMY of $1^{\text {st }}$ year and $2^{\text {nd }}$ year of use of plots in each year of observation. The highest DMYs were harvested in the years 2015 and 2016. Dry matter yield of the $1^{\text {st }}$ cut was the largest component of the total DMY for most of the years. The plants overwintered the first winter after sowing very well over the whole study period, resulting in excellent spring growth. The winter survival scores of $2^{\text {nd }}$ year of use of plots were lower than $1^{\text {st }}$ year of use and strongly correlated with the $1^{\text {st }}$ cut DMY of $2^{\text {nd }}$ year of use $(r=0.81)$. Spring growth of plants at $2^{\text {nd }}$ year of use was poorer, the correlation between winter survival and spring growth of $2^{\text {nd }}$ year of use was 0.62 . The scores of regrowth after the cuts of $1^{\text {st }}$ and $2^{\text {nd }}$ years of use were very similar for most of the experimental years and moderately correlated with the sum of DMYs after cuts $(r=0.55$ and $r=0.5$, respectively).
\end{abstract}

Additional key words: crown rust, dry matter yield, intergeneric hybrids, leaf spot diseases, winter survival.

\section{Introduction}

In recent years, the observed weather anomalies left no doubts about climate change and its effect on crop productivity in Europe and worldwide. Climate change trends, in particular rising temperatures, altered amounts and pattern of precipitation, prolonged growing season affects overwintering, growth and development of forage grasses at the cultivar or even species level resulting in frequent losses of yield (Kipling et al. 2016). Moreover, climate change may impact grassland composition and grassland quality, having consequences on feed production for livestock (Ergon et al. 2018). In order to meet the challenges that climate change will bring and to improve the production of perennial herbage plants, both breeders and farmers should carefully choose the cultivated species.

The breeders aim at combining the best traits of different species and even genera resulted in a new grass genus - Festulolium. It is the hybrid between fescue (Festuca) species and ryegrass (Lolium) species offering the possibility of combining superior agricultural traits, such as excellent feeding quality of ryegrass with the persistency and stress tolerance of fescue into one single plant (Ghesquière et al. 2010a, Thomas et al. 2003). Festulolium is valued for quick establishment, weed suppression determined by its aggressive growth, as well as very good winter survival and regrowth capacity, thus high yields (Ghesquiere et al. 2010b, Østrem et al. 2013, Jiao et al. 2017).

In Lithuania, Festulolium breeding program was initiated in 1979 when the first interspecific crosses were performed at LAMMC Institute of Agriculture, former Lithuanian Institute of Agriculture. Various crossing combinations have been used in breeding programs which

Submitted 18 September 2020, last revision 11 November 2020, accepted 13 November 2020.

Abbreviations: DMY1 - dry matter yield of the first cut; DMY2 - dry matter yield of the second cut; DMY3 - dry matter yield of the third cut; DMY4 - dry matter yield of the fourth cut; RG - regrowth after cuts; SG - spring growth; WS - winter survival; Y1 - first year of use; Y2 - second year of use.

Acknowledgements: The study was carried out in the frame of the long-term research program "Genetic determination of the traits of agricultural and forest plants, development of modern cultivars" and the "Genome-wide functional analysis of perennial ryegrass for improved growth under water liming conditions (GrowGene)" project funded by the Research Council of Lithuania, Grant No. S-MIP-17-24.

* Corresponding author; e-mail: grazina.statkeviciute@lammc.lt 
resulted in four cultivars, namely Punia DS, Puga, Vètra, and Lina DS, registered in the Common European Variety List. Two of the registered cultivars, Punia DS and Puga, were obtained from crosses between $F$. pratensis and L. multiflorum ssp italicum, Vètra was developed from crossing $F$. arundinaceae and L. multiflorum ssp italicum, and Lina DS resulted from crossing $F$. pratensis and L. multiflorum ssp multiflorum (Nekrošas and Kemešytė 2007). All cultivars are highly tolerant to diseases and have good overwintering, in particular Punia DS, where the maternal plant was Festuca pratensis (Lemežiene et al. 2004, Nekrošas and Kemešytė 2007). Festuca species are known for their persistence under unfavourable conditions (Sandve et al. 2011), thus Festulolium cultivars maintaining these agriculturally important traits become increasingly relevant with more extreme environmental conditions. In terms of Lithuanian climatic conditions, Festulolium cultivars are widely utilized because of their good winter survival over the harsh winters and still the production of high yields (Lemežienè et al. 2004). However, due to climate change, winter patterns have changed to milder requiring adaptation of plants to prolonged vegetation season, to cope with spells of freezing temperatures with less or without snow cover. Moreover, increased air temperature, water shortage and unpredictable precipitation distribution during the growing season challenge Festulolium cultivars to maintain the yield over the whole growing season.

In this study we have chosen two Festulolium cultivars of different cross combination and aimed at 1 ) evaluating their performance in field trials over the period of seven years and 2) assessing the yield stability under fluctuating weather conditions.

\section{Materials and methods}

Plants and field experiments: Two tetraploid loloid type Festulolium cultivars Punia DS and Lina DS were evaluated in the field experiments. The experiments were carried out at LAMMC Institute of Agriculture $\left(55^{\circ} 23^{\prime} \mathrm{N}\right.$, $\left.23^{\circ} 57^{\prime} \mathrm{E}\right)$ over the period of $2013-2019$. One experimental cycle, which started in 2014 and comprised of a year of sowing and two years of use, was omitted. The experiment was set up in $7.5-13.25 \mathrm{~m}^{2}$ test plots using a randomized complete block design with 3 replications.

The soil of the experimental fields was Endocalcari Epihypogleyic Cambisols (CMg-p-w-can), characterized by a homogeneous texture, $\mathrm{pH} \mathrm{KCl} 7.3$ - 7.0, humus content 1.9 - $2.2 \%$, available $\mathrm{P}_{2} \mathrm{O}_{5} 206$ - $270 \mathrm{mg} \mathrm{kg}^{-1}$, and $\mathrm{K}_{2} \mathrm{O} 101-154 \mathrm{mg} \mathrm{kg}^{-1}$. In the autumn of each year of use $6 \mathrm{~g}\left(\mathrm{P}_{2} \mathrm{O}_{5}\right) \mathrm{m}^{-2}$ and $9 \mathrm{~g}\left(\mathrm{~K}_{2} \mathrm{O}\right) \mathrm{m}^{-2}$ fertilizers were applied. Nitrogenous fertilizers were applied each year of herbage use in several applications: in spring $6 \mathrm{~g}(\mathrm{~N}) \mathrm{m}^{-2}$, and $4.5 \mathrm{~g}(\mathrm{~N}) \mathrm{m}^{-2}$ after each cut, except the last one.

To determine the dry matter yield (DMY), $0.5 \mathrm{~kg}$ of fresh biomass of each sample was oven-dried at $105^{\circ} \mathrm{C}$ to constant mass. The plots were harvested 3 - 4 times per year depending on the meteorological conditions; herbage yield $\left(\mathrm{kg} \mathrm{m}^{-2}\right)$ was assessed as production per plot. At the beginning of heading stage plots were cut for the first time, while the second, third, and fourth cuts were taken after the plants reached $\geq 20 \mathrm{~cm}$ height. Winter survival and spring growth, disease resistance, re-growth after cuts were assessed in scores, where 1 is very low, 3 - low, 5 - medium, 7 - high, 9 - very high value of the trait. The beginning of the heading was recorded when more than $50 \%$ of plants emerged.

Meteorological data: According to the environmental stratification of Europe, Lithuania is assigned to nemoral zone with a cool temperate climate and quite short growing season of 190 - 195 d (Metzger et al. 2012). Daily meteorological data (mean, minimal, and maximal temperatures, precipitation and snow cover) over the period of 2013 - 2019, recorded at the meteorological station in Noreikiškès, Kaunas region $\left(54^{\circ} 52^{\prime} \mathrm{N}, 23^{\circ} 50^{\prime} \mathrm{E}\right)$ were obtained from the Ogimet repository by using 'climate' package for $R$ (Czernecki et al. 2020).

Winter period was considered to start since the first day when $\mathrm{T}_{\min } \leq-10^{\circ} \mathrm{C}$, cold days were considered when $\mathrm{T}_{\min }$ is $\leq-15^{\circ} \mathrm{C}$, while the warm days when $\mathrm{T}_{\text {mean }} \geq 0{ }^{\circ} \mathrm{C}$ (Bélanger et al. 2002, Thorsen and Höglind 2010). Degree days (DD) were calculated with the base temperature of $5{ }^{\circ} \mathrm{C}$. The average annual precipitation at the experimental site is $550-600 \mathrm{~mm}$ and the average annual temperature is 6.0 $6.5{ }^{\circ} \mathrm{C}$ (Fig. 1 Suppl.). The mean length of winter season over the experimental period was $110.3 \mathrm{~d}$. The shortest winter season was in 2013/2014 lasting for $66 \mathrm{~d}$, while the winter of 2013 and 2015 was the longest - $134 \mathrm{~d}$. The winter of 2013 was distinguished by permanent snow cover and mean temperatures below $0{ }^{\circ} \mathrm{C}$, however without extreme cold spells (Fig. 1 Suppl.). The winter season of 2018 was short, lasting $86 \mathrm{~d}$, nevertheless, it was characterized by the highest number of cold days, when the minimum temperature dropped below $-15^{\circ} \mathrm{C}$ and with very low snow insulation. Cool and rainy spring was recorded in 2017, while in August 2015 and June 2016 the drought occurred, no precipitation was recorded for 25 and $20 \mathrm{~d}$, respectively. The longest vegetation season was in summer of 2017, though this season was the coolest, characterized by the lowest value of DD throughout all the cuts (Table 1 Suppl.). The same trends were also observed for the summer of 2016. The shortest growing season was observed in 2015; moreover, it was one of the driest, with only $174,9 \mathrm{~mm}$ of rainfall, and one of the coolest (Table 1 Suppl.). Summers of 2018 and 2019 were characterized by the highest DDs over all periods from one cut to another, also as very dry seasons having the least amount and frequency of rainfall. In contrast, the vegetation season of 2017 is featured the highest percentage of rainy days $(87 \%)$ and the most intensive rainfall of $477.4 \mathrm{~mm}$ (Table 1 Suppl.).

Statistical analysis was implemented in the open-source $R$ statistical environment v. 4.0.2 ( $R$ Core Team 2020, $R$ Foundation for Statistical Computing, Vienna 2020). Basic descriptive statistics was calculated using $R$ package 'metan' function desc_stat (Olivoto and Lúcio 2020), analysis of variance and post-hoc tests were conducted using the R package 'agricolae' (De Mendiburu and Yaseen 2020). To estimate genotype and environment interaction 
and effect on DMY, ANOVA and subsequently post hoc Tukey HSD test was applied. The Kruskal-Wallis test was used for analyzing the influence of year on qualitative traits and Fisher's least significant difference with Bonferroni correction was applied to test for significant differences between the trait means.

\section{Results}

The mean total DMY of both Festulolium cultivars fluctuated greatly between the years, ranging from 0.67 to $1.22 \mathrm{~kg} \mathrm{~m}^{-2}$ in $1^{\text {st }}$ year of use (Y1) and from 0.19 to $0.64 \mathrm{~kg} \mathrm{~m}^{-2}$ in $2^{\text {nd }}$ year of use (Y2) (Fig. 1). ANOVA analysis showed a significant effect $(P<0.001)$ of the environment on total DMY as well as DMY of each cut. However, the genotype and environment interactions were not significant; therefore, only means over the two cultivars are reported. The lowest total DMY of Y1 was obtained in 2013, whereas the highest total DMY of Y1 was obtained in 2016. The highest total DMY of Y2 was recorded in 2015, the lowest in 2018. The dry matter yield of the $1^{\text {st }}$ cut (DMY1) was the largest component of the total DMY except for 2013 and 2014, when it did not differ from the $2^{\text {nd }}$ cut (DMY2) in the Y1 plots and was the smallest part of total DMY of the Y2. In 2016 and 2017 it was possible to harvest the $4^{\text {th }}$ cut in Y1, and in both Y1 and $Y 2$ in 2019. DMY3 was the most variable DMY part in the $\mathrm{Y} 1, \mathrm{cv}=48 \%$; DMY1 was the most variable yield component in the Y2 $(\mathrm{cv}=69 \%)$. Total DMY of Y2 plots was significantly lower than that of Y1 plots (considered $100 \%$ ), with a reduction of $43.5 \%$ (2019) to $79 \%$ (2018) and an average reduction of $61.4 \%$ over all years. The highest yield difference was estimated in 2014 between the DMY1 $(84.5 \%)$ and the lowest one was in DMY3 of 2017 , only $0.4 \%$.
The Y1 plots survived the first winter of the cycle very well, mean winter survival (WS) was 8.3 to 9 , with the only exception being 2014 (mean WS score 6.4) (Fig. 2). The WS of Y1 was the only trait with significant cultivar effect: the differences between Punia DS and Lina DS were not statistically significant in each year, however, Lina DS scored steadily lower, resulting in lower mean winter survival $(P<0.05)$ over the whole period of investigation. The WS scores of Y2 plots were lower than Y1 but still rather high, the mean scores of 2015 - 2019 varied from 7.8 to 8.8 . The plots suffered a greater winter damage only in 2013 and 2014 (WS score 4.7 to 5) (Fig. 2B). Strong correlation was estimated between WS of Y2 and DMY1 of Y2 ( $r=0.81, P<0.001, n=12)$. Spring growth (SG) score of Y1 plants was high in all years, ranging from 7.9 to $9(\mathrm{SD}=0.40)$. Y2 plots exhibited poorer SG and higher variation of this trait $(\mathrm{SD}=1.36)$, with minimum SG score 4.8 (2013) and maximum 8.8 (2015 and 2017). The correlation between WS and SG of Y2 was 0.62 $(P<0.001)$. Regrowth after cuts $(\mathrm{RG})$ score ranged from 6.7 to 8.8 in $\mathrm{Y} 1$ and from 4 to 7.5 in $\mathrm{Y} 2$. RG scores of $\mathrm{Y} 1$ and Y2 were very similar in 2013 and 2019, the highest RG score difference was reported in 2018 (RG of Y1 score was 7.1, RG of Y2 score was 4). A moderate correlation was estimated between RG and sum of DMYs after cuts in both $\mathrm{Y} 1$ and $\mathrm{Y} 2$ plots $(r=0.55$ and $r=0.5$, respectively, $P<0.01)$.

Plant height fluctuated between 53 to $107 \mathrm{~cm}$ (Y1) and 44 to $112 \mathrm{~cm}$ (Y2) during $2013-2019$ period (Fig. $3 A$ ). In general, Y1 plots tended to be taller than Y2 plants except for 2014. The greatest height difference was measured in 2018, when Y2 plots were shorter that Y1 plots by $47 \%$. There was a moderate correlation between plant height and total DMY for the Y1 trials $(r=0.49, P<0.05)$.

In all years of investigation, the heading was recorded in May, ranging from $21^{\text {st }}$ to $31^{\text {st }}$ (Fig. $3 B$ ). The latest

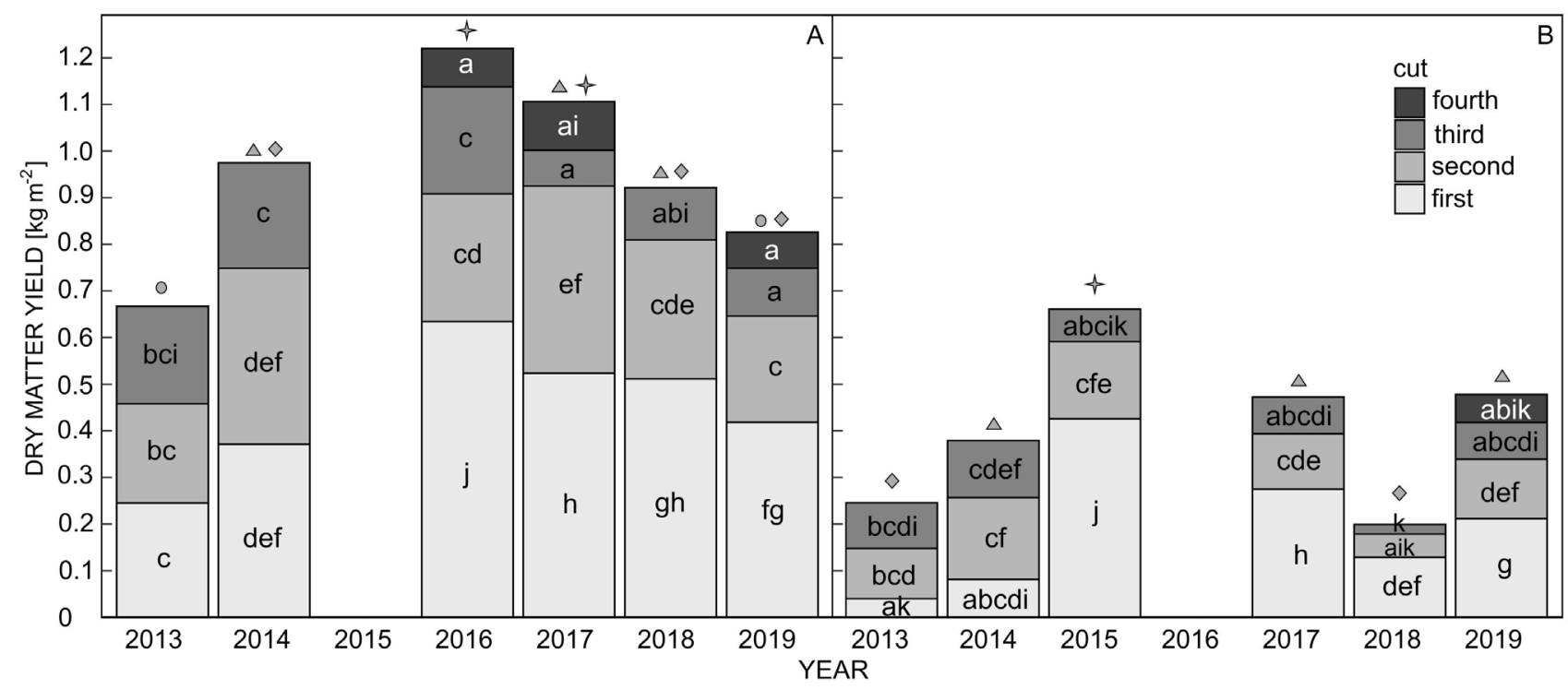

Fig. 1. The mean dry matter yield (DMY) of two Festulolium cultivars during the period of seven years. Means \pm SDs, $n=6$. Within either the first year of use $(A)$ or the second year of use $(B)$, individual cuts denoted with the same letter, and total annual DMY columns topped with the same symbol, are not significantly different (Tukey's honestly significant difference test, $P>0.05$ ). 


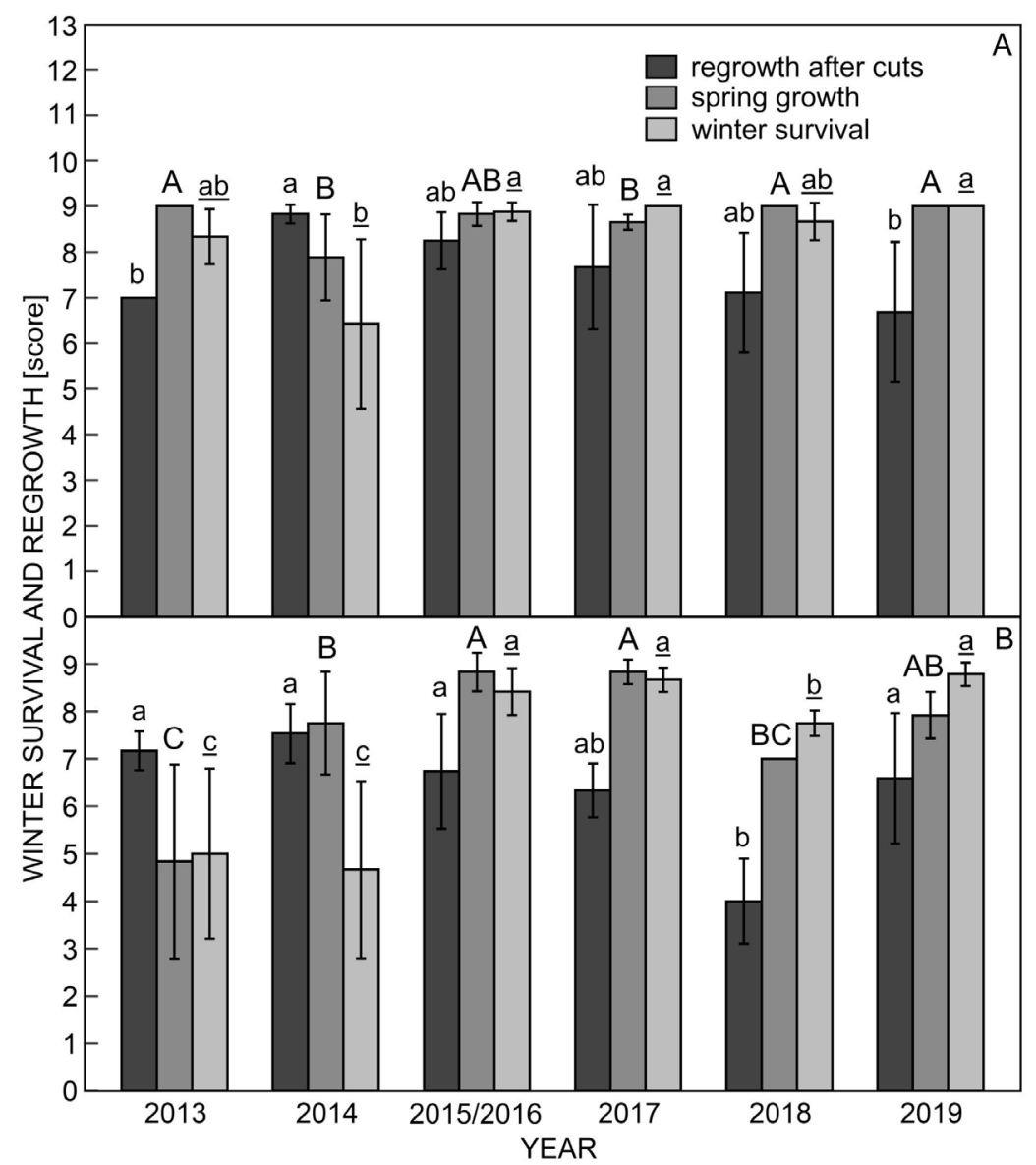

Fig. 2. The mean score of winter survival, re-growth in spring, and after the cuts of two Festulolium cultivars over the period of 20132019. The scores of the first year of use are presented in $A$ and the scores of the second year of use in $B$. Means $\pm \mathrm{SDs}, n=6$. The letters indicate difference among years, where winter survival is specified with a lowercase letter, while regrowth in spring, and after cuts are represented by uppercase and underlined letters, respectively (Fisher's least significant difference test with Bonferroni correction, $P<0.05)$.

heading date of both Y1 and Y2 trials was recorded in 2017. Punia DS and Lina DS reached the heading stage at the same time or differed by only $1 \mathrm{~d}$.

The mean crown rust and leaf spot disease infection scores ranged from 1 to 5.5 (Fig. 4). Both diseases were most prevalent in 2013 (mean crown rust score 5.2, mean leaf spot score 5.4) and least prevalent in 2019. The two cultivars did not differ in their disease resistance, the only significant environmental effect was confirmed by analysis of variance.

\section{Discussion}

Festulolium grasses, the interspecific hybrids between Lolium and Festuca, have been developed as an alternative to existing Lolium and Festuca cultivars as they featured superior resilience against abiotic stresses compared to perennial ryegrass (Ghesquière et al. 2010a,b, Humphreys et al. 2010). Festulolium cultivars are of similar forage quality as ryegrass (Humphreys et al. 2003), but their winter hardiness is typically lower than their parental Festuca species (Brink et al. 2010). The main reason limiting the cultivation of ryegrasses in the Baltic region is their susceptibility to harsh winter conditions and subsequently low persistence (Kemesyte et al. 2017). It was demonstrated in the previous 13 years-long study, that perennial ryegrass is the least winter-hardy, compared to other forage grass species (Lemežienè et al. 2004), including Festulolium, under Lithuanian conditions. Festulolium cultivars, used in this study, offered high winter survival in the first year of use and excellent spring growth, resulting in high dry matter yields of the first cut. The record of low yield in 2013 was most likely determined by a short spring growth period rather than harsh winter. In general, autumn periods became longer and warmer than the long-term average in the recent decade in Lithuania as well as elsewhere in the Northern-Baltic region (Ergon et al. 2018). This phenomenon allowed to harvest the $4^{\text {th }}$ cut in the first year of use in 2016, 2017 and 2019. Furthermore, long warm autumns allow successful cultivation of southern-adapted forage grass populations (Dalmannsdóttir et al. 2015), thus expanding the choice of cultivar for farmers. However, high autumn temperatures delay the start of the hardening period, which can negatively impact plant resistance to stress factors during winter (Ergon et al. 2018). Insufficient 


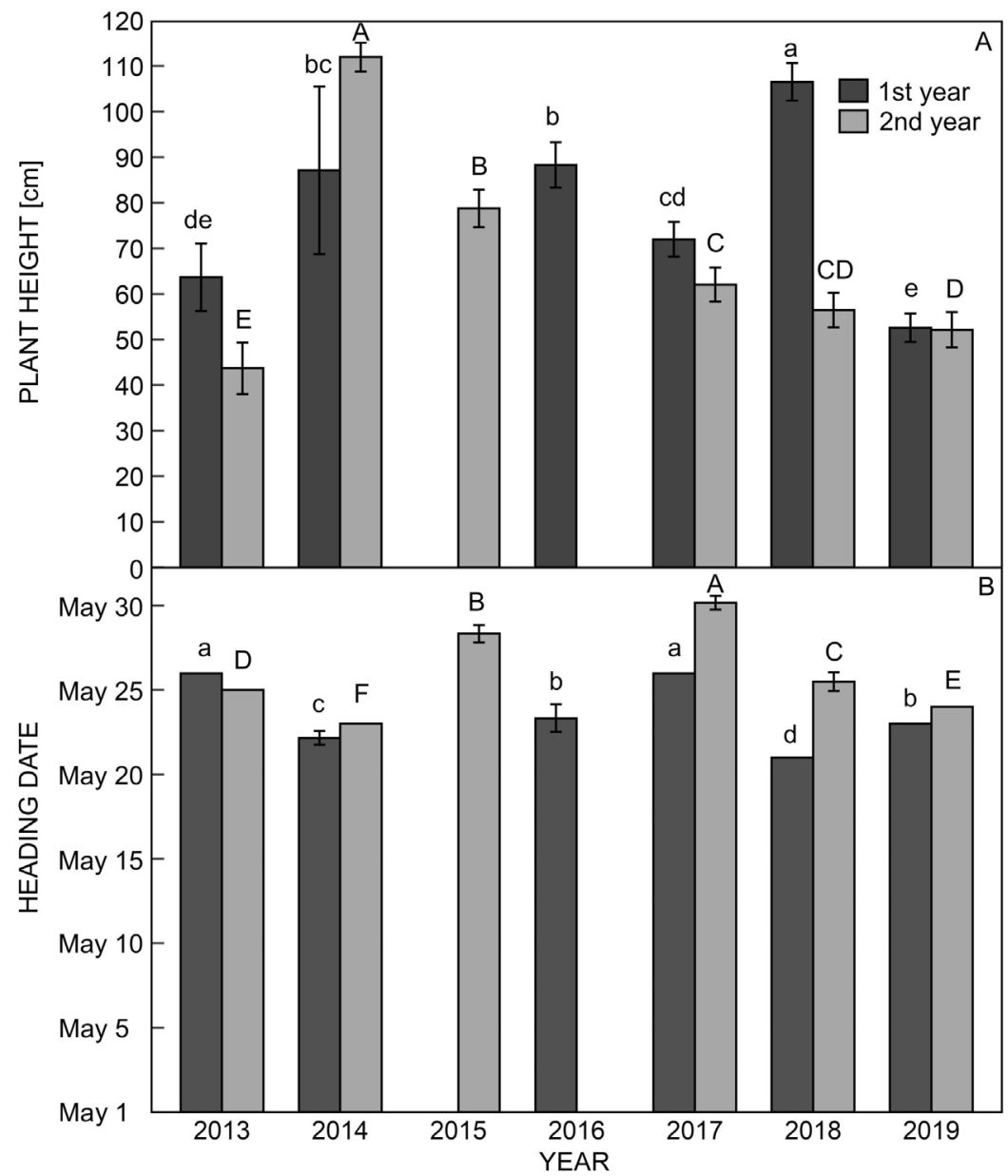

Fig. 3. The mean values of plant height and heading date of two Festulolium cultivars over the period of 2013-2019. Plant height is shown in $A$, where the difference between the first and second years of use are specified with lowercase and uppercase letters, respectively (Tukey's honestly significant difference test, $P<0.05$ ). Heading date is given in $B$, where lowercase letters denote differences between years of the first year of use, and uppercase of the second year of use (Fisher's least significant difference test with Bonferroni correction, $P<0.05)$. Means \pm SDs, $n=6$.

acclimation most likely reduced winter survival in 2014 : most of the winter period was much warmer than 2013, but a sudden drop of mean temperatures below $-12{ }^{\circ} \mathrm{C}$ for 2 weeks with thin snow cover led to lower winter survival scores. The similar winter weather pattern was observed in 2016, but plants were most likely protected by the thicker snow cover. The highest total dry matter yield was obtained in the rather cool and rainy growing season of 2016, whereas heatwaves and drought spells of 2018 and 2019 significantly reduced the yields. Festulolium of loloid type is less resistant to drought than fescues, especially tall fescue (Fariaszewska et al. 2016), but more resistant than perennial ryegrass, most likely due to the deeper, betterdeveloped root system (Humphreys et al. 2018), making it a more suitable high-quality forage source in the future. Another concern related to climate change is the possibility of increased incidence and severity of plant diseases in the Northern regions (Ergon et al. 2018). Crown rust and leaf spots were observed in all years of this study, however, the infection was not severe except in 2013, indicating that at least for the nearest future forage grass breeders do not have to shift their efforts in this direction. However, the sward persistence was still the major issue. Both Festulolium cultivars suffered high yield reduction in the second year of use, especially in the growing season of 2018, which was the hottest and driest throughout the span of seven years of study, indicating that long-lasting grasslands can only be achieved with significant improvement of plant drought resistance. However, breeding for winter hardiness should not be abandoned either. Even though winters are predicted to get warmer in Northern Europe, the lack of adequate acclimation together with extreme weather events during winter can still lead to substantial yield losses.

Festulolium breeding, even though rather complicated due to the nature of interspecific crossing, can potentially be highly rewarding as the resulting hybrids can comprise the best traits of parental species, far exceeding the trait variation boundaries of parental species. The vast majority of Festulolium cultivars were developed by crossing Lolium perenne or L. multiflorum on the Lolium genus side and Festuca pratensis or to the lesser extent F. arundinacea on Festuca genus side (Kopecký et al. 2008). However, Festuca is a large genus, its complex phylogeny is being explored to this day (Cheng et al. 2016, 


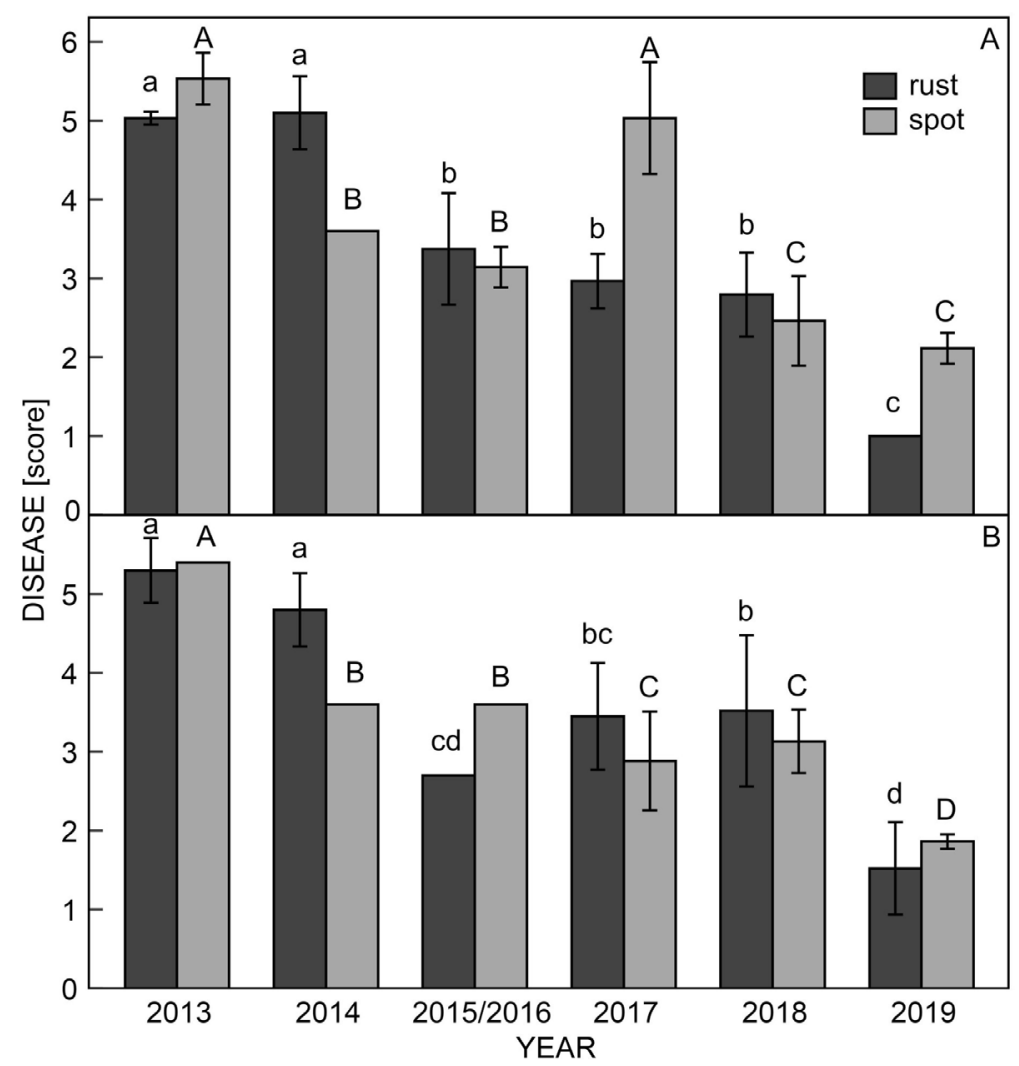

Fig. 4. The mean score of crown rust and leaf spot diseases of two Festulolium cultivars over the period of seven years. $A$ and $B$ show the mean scores of the first and second years of use, respectively. Means \pm SDs, $n=6$. Differences among years are denoted with lowercase letters for crown rust and uppercase letters for leaf spot diseases (Fisher's least significant difference test with Bonferroni correction, $P<0.05)$.

Qiu et al. 2019), so the possibilities for the breeders to experiment are nearly limitless. Both Festulolium cultivars in this study came from the crosses with $F$. pratensis. However, this fescue species might not be the best choice as it is less resistant to drought and has a lower root mass and diameter than F. arundinacea (Wilman et al. 1998, Cougnon et al. 2017). Other fescue species, successfully applied in the development of highly productive hybrids, are $F$. arundinacea var. glaucescens and $F$. mairei (Ghesquière and Bourgoin, 2010, Humphreys et al. 2014). $F$. arundinacea and $F$. rubra has been included in the recently re-opened Festulolium breeding programme in Lithuania as well, however, further investigation is needed to evaluate whether these new hybrids have superior stress tolerance and persistence compared to currently grown cultivars.

\section{References}

Bélanger, G., Rochette, P., Castonguay, Y., Bootsma, A., Mongrain, D., Ryan, D.A.J.: Climate change and winter survival of perennial forage crops in Eastern Canada. - Agron. J. 94: 1120-1130, 2002.

Brink, G.E., Casler, M.D., Martin, N.P.: Meadow fescue, tall fescue, and orchardgrass response to defoliation management. - Agron. J. 102: 667-674, 2010.

Cheng, Y., Zhou, K., Humphreys, M.W., Harper, J.A., Ma, X.,
Zhang, X., Yan, H., Huang, L.: Phylogenetic relationships in the Festuca-Lolium complex (Loliinae; Poaceae): new insights from chloroplast sequences. - Front. Ecol. Evol. 4: 1-12, 2016.

Cougnon, M., De Swaef, T., Lootens, P., Baert, J., De Frenne, P., Shahidi, R. Roldán-Ruiz, I., Reheul, D.: In situ quantification of forage grass root biomass, distribution and diameter classes under two N fertilisation rates. - Plant Soil 411: 409-422, 2017.

Czernecki, B., Glogowski, A., Nowosad, J.: Climate: An R package to access free in-situ meteorological and hydrological datasets for environmental assessment. - Sustainability 12: undefined, 2020.

Dalmannsdóttir, S., Rapacz, M., Jørgensen, M., Østrem, L., Larsen, A., Rødven, R., Rognli, O.A.: Temperature before cold acclimation affects cold tolerance and photoacclimation in timothy (Phleum pratense L.), perennial ryegrass (Lolium perenne L.) and red clover (Trifolium pratense L.). - J. Agron. Crop Sci. 202: 320-330, 2015.

De Mendiburu, F., Yaseen, M.: Agricolae: Statistical Procedures for Agricultural Research. R package version 1.3-3, https:// CRAN.R-project.org/package=agricolae, 2020.

Ergon, Å., Seddaiu, G., Korhonen, P., Virkajärvi, P., Bellocchi, G., Østrem, L., Reheul, D., Volaire, F.: How can forage production in Nordic and Mediterranean Europe adapt to the challenges and opportunities arising from climate change? Eur. J. Agron. 92: 97-106, 2018.

Fariaszewska, A., Aper, J., Van Huylenbroeck, J., Baert, J., De Riek, J., Staniak, M., Pecio, Ł.: Mild drought stress-induced changes in yield, physiological processes and chemical 
composition in Festuca, Lolium and Festulolium. - J. Agron. Crop Sci. 203: 103-116, 2016.

Ghesquière, M., Bourgoin, T.: Seed yield of new Festulolium varieties bred from $F$. arundinacea var. glaucescens. - In: Huyghe C. (ed.): Sustainable use of Genetic Diversity in Forage and Turf Breeding. Pp. 529-534. Springer, Dordrecht 2010.

Ghesquiere, M., Humphreys, M., Zwierzykovski, Z.: Festulolium. - In: Boller B. (ed.): Fodder Crops and Amenity Grasses. Pp. 293-316. Springer, New York 2010a.

Ghesquière, M., Humphreys, M., Zwierzykowski, Z.: Festulolium hybrids: results, limits and prospects. - In: Huyghe, C. (ed.): Sustainable Use of Genetic Diversity in Forage and Turf Breeding. Pp. 495-507. Springer, Dordrecht 2010b.

Humphreys, M., Feuerstein, U., Vandewalle, M., Baert J.: Ryegrasses. - In: Boller B. (ed.): Fodder Crops and Amenity Grasses. Pp. 211-260. Springer, New York 2010.

Humphreys, M.W., Canter, P.J., Thomas, H.M.: Advances in introgression technologies for precision breeding within the Lolium - Festuca complex. - Ann. appl. Biol. 143: 1-10, 2003.

Humphreys, M.W., Doonan, J.H., Boyle, R., Rodriguez, A.C., Marley, C.L., Williams, K., Farrell, M.S., Brook, J., Gasior, D., Loka, D., Collins, R.P., Marshall, A.H., Allen, D.K., Yadav, R.S., Dungait, J.A.J., Murray, P., Harper, J.A.: Root imaging showing comparisons in root distribution and ontogeny in novel Festulolium populations and closely related perennial ryegrass varieties. - Food Energy Security 7: 1-10, 2018.

Humphreys, M.W., O'Donovan, S.A., Farrell, M.S., Gay, A.P., Kingston-Smith, A.H.: The potential of novel Festulolium (2n $=4 x=28$ ) hybrids as productive, nutrient- use-efficient fodder for ruminants. - Food Energy Security 3: 98-110, 2014

Jiao, X., Kørup, K., Andersen, M.N., Sacks, E.J., Zhu, X.G., Lærke, P.E., Jørgensen, U.: Can Miscanthus C4 photosynthesis compete with Festulolium $\mathrm{C} 3$ photosynthesis in a temperate climate? - GCB Bioenergy 9: 18-30, 2017.

Kemesyte, V., Statkeviciute, G., Brazauskas, G.: Perennial ryegrass yield performance under abiotic stress. - Crop Sci. 57: 1935-1940, 2017.

Kipling, R.P., Virkajärvi, P., Breitsameter, L., Curnel, Y., De Swaef, T., Gustavsson, A.M., Hennart, S., Höglind, M., Järvenranta, K., Minet, J., Nendel, C., Persson, T., PiconCochard, C., Rolinski, S., Sandars, D.L., Scollan, N.D., Sebek, L., Seddaiu, G., Topp, C.F.E., Twardy, S., Van Middelkoop,
J., Wu, L., Bellocchi, G.: Key challenges and priorities for modelling European grasslands under climate change. - Sci. total Environ. 566-567: 851-864, 2016.

Kopecký, D., Lukaszewski, A.J., Doležel, J.: Cytogenetics of Festulolium (Festuca $\times$ Lolium hybrids). - Cytogenet. Genome Res. 120: 370-383, 2008.

Lemežienė, N., Kanapeckas, J., Tarakanovas, P., Nekrošas, S.: Analysis of dry matter yield structure of forage grasses. Plant Soil Environ. 50: 277-282, 2004.

Metzger, M.J., Shkaruba, A.D., Jongman, R.H.G., Bunce, R.G.H.: Descriptions of the European Environmental Zones and Strata (Alterra Report 2281). - Alterra, Wageningen 2012.

Nekrošas, S., Kemešyte, V.: Breeding of ryegrass and Festulolium in Lithuania. - Zemdirbyste-Agriculture 94: 29-39, 2007.

Olivoto, T., Lúcio, A.D.C.: Metan: an R package for multienvironment trial analysis. - Methods Ecol. Evol. 11: 783789, 2020.

Østrem, L., Volden, B., Larsen, A.: Morphology, dry matter yield and phenological characters at different maturity stages of $\times$ Festulolium compared with other grass species. - Acta agr. scand. Sect. B Soil Plant Sci. 63: 531-542, 2013.

Qiu, Y., Hirsch, C.D., Yang, Y., Watkins, E.: Towards improved molecular identification tools in fine fescue (Festuca L., Poaceae) turfgrasses: nuclear genome size, ploidy, and chloroplast genome sequencing. - Front. Genet. 10: 1-12, 2019.

Sandve, S.R., Kosmala, A., Rudi, H., Fjellheim, S., Rapacz, M., Yamada, T., Rognli, O.A.: Molecular mechanisms underlying frost tolerance in perennial grasses adapted to cold climates. Plant Sci. 180: 69-77, 2011.

Thomas, H.M., Morgan, W.G., Humphreys, M.W.: Designing grasses with a future - combining the attributes of Lolium and Festuca. - Euphytica 133: 19-26, 2003.

Thorsen, S.M., Höglind, M.: Assessing winter survival of forage grasses in Norway under future climate scenarios by simulating potential frost tolerance in combination with simple agroclimatic indices. - Agr. Forest. Meteorol. 150: 1272-1282, 2010.

Wilman, D., Gao, Y., Leitch, M.H.: Some differences between eight grasses within the Lolium-Festuca complex when grown in conditions of severe water shortage. - Grass Forage Sci. 53: 57-65, 1998. 